\title{
Obligations, consent and contracts in Scots law: re-analysing the basis of medical malpractice liability in light of Montgomery $v$ Lanarkshire Health Board
}

\author{
Jonathan Brown* \\ University of Strathclyde, Glasgow, UK \\ *Author e-mail: Jonathan.brown@strath.ac.uk
}

(Accepted 19 November 2020)

\begin{abstract}
Professors MacQueen and Thomson have defined 'contract', within Scots law, as denoting 'an agreement between two or more parties having the capacity to make it, in the form demanded by law, to perform, on one side or both, acts which are not trifling, indeterminate, impossible or illegal'. This definition reflects the fact that Scottish contracts are underpinned by consent, rather than by 'consideration'. This, naturally, has the potential to be of great significance within the context of physician/patient relationships, particularly since the 2006 case of Dow $v$ Tayside University Hospitals NHS Trust acknowledged that these relationships could be contractual in nature. This observation is of renewed importance since the landmark decision in Montgomery $v$ Lanarkshire Health Board, which found that physicians must ensure that they obtain full and freely given 'informed consent' from their patients, prior to providing medical services. In light of the present medical regime which requires 'doctor and patient [to] reach agreement on what should happen', the basis of liability for medical negligence, in Scotland, requires reanalysis: 'To have a contract only when the patient pays is not consistent with a legal system which has no doctrine of consideration in contract'.
\end{abstract}

Keywords: contract; delict; injury; negotiorum gestio; actio iniuriarum; informed consent

\section{Introduction}

Professors MacQueen and Thomson have defined 'contract' as 'an agreement between two or more parties having the capacity to make it, in the form demanded by law, to perform, on one side or both, acts which are not trifling, indeterminate, impossible or illegal'. ${ }^{1}$ That this definition recognises the possibility, outside the concurrent creation of some formal deed, ${ }^{2}$ of a gratuitous contract (ie a contract which is not underpinned by consideration) may puzzle Anglo-American lawyers, ${ }^{3}$ but Scots law, following Canon law in repudiating the maxim ex nudo pacto actio non oritur [no action

\footnotetext{
${ }^{1}$ HL MacQueen MacQueen and Thomson on Contract Law in Scotland (Bloomsbury Professional, $5^{\text {th }}$ edn, 2020) para 1.10.

${ }^{2}$ See H Beale Chitty on Contracts vol 1 (Sweet \& Maxwell, $33^{\text {rd }}$ edn, 2019) para 1-143.

${ }^{3 c}$ In English law, a promise is not, as a general rule, binding as a contract unless it is either made in a deed or supported by some "consideration"': ibid, para 4-001. By contrast, sentences such as this, or to the effect that 'a promise, to be binding as a contract, must be supported by consideration' (from R Duxby Contract Law (Sweet \& Maxwell, $2^{\text {nd }}$ edn, 2011) para 1-008) are wholly unmeaning in Scots law. Scots law recognises, as binding, unilateral promises (pollicitatio) which are wholly distinct in nature from contracts and which can be functionally and fruitfully contrasted with offers: see eg Lord Blantyr $v$ Kennoway (1612) Hope II 3, 34. A promise, in Scots law, cannot be equated with an offer, but rather is that which is simple and pure, and hath not implyed [sic], as a condition, the acceptance of another': Stair Institutions I, 10, 4.

(c) The Author(s), 2021. Published by Cambridge University Press on behalf of The Society of Legal Scholars. This is an Open Access article, distributed under the terms of the Creative Commons Attribution licence (https://creativecommons.org/licenses/by/4.0/), which permits unrestricted re-use, distribution, and reproduction in any medium, provided the original work is properly cited.
} 
arises from a bare agreement,${ }^{4}$ has long recognised that 'every paction produceth action, et omne verbum de ore fideli cadit in debitum' [and every word spoken in faith creates a debt]. ${ }^{5}$ Thus, the Scots law of obligations accepts, as binding, agreements which are not underpinned by any 'consideration' ${ }^{6}$ as well as unilateral promises ${ }^{7}$ - even where the content of said promise is not communicated to the beneficiary of the promise. ${ }^{8}$ Contracts and binding promises are formed, then, where the contracting parties or the promisor 'engage' with another person (who may potentially be innominate, the engagement being directed to the world at large $)^{9}$ so as to demonstrate an intention to create, and be bound by, a legal obligation. ${ }^{10}$

Consent, rather than 'consideration', thus underpins all contracts governed by Scots law. ${ }^{11}$ This, naturally, has the potential to be of great significance within the context of Scottish NHS physician/ patient relationships, ${ }^{12}$ particularly since the 2006 case of Dow $v$ Tayside University Hospitals NHS Trust $^{13}$ acknowledged that these relationships could conceivably be contractual (or indeed promissory) in nature. ${ }^{14}$ Though this case attracted little subsequent scholarly or judicial comment, ${ }^{15}$ the observations of counsel and of Sheriff Fletcher are of renewed importance since the landmark decision in Montgomery $v$ Lanarkshire Health Board. ${ }^{16}$ In that case, the UK Supreme Court (UKSC) found that physicians must ensure that they obtain full and freely given 'informed consent' from their patients, prior to providing medical services.

At the time at which Dow was decided - indeed, immediately prior to the UKSC decision in Montgomery itself - it was still possible for legal academics and commentators to claim that 'the doctrine of informed consent has not made its way into Scots law. ${ }^{17}$ The veracity of this statement is apparent from the appellate history of Montgomery. At first instance, and on appeal, the Court of Session found that the law held that it was typically for physicians to determine, for themselves as a class, whether or not information about procedural risks should be provided to their patients in advance of treatment. ${ }^{18}$ If disclosure of the information was not thought to be in the 'best interests' of the patient, ${ }^{19}$ then there would be no duty to disclose, let alone discuss, the information in

\footnotetext{
${ }^{4}$ Dig 2.14.7.4 posits the rule nuda pactio obligationem non parit [bare agreement does not create an obligation]; the common law, by contrast, tends to prefer the formulation listed in the text above, while Stair, for his part, preferred the formulation nudum pactum inefficax ad agendum [a bare agreement is ineffective and creates no obligation].

${ }^{5}$ Stair Institutions I, 10, 7.

${ }^{6}$ See generally RS ‘Art I: the law of contracts in England and Scotland' [1859] (42-43) Law Mag \& Rev Quart Rev Juris 209 at 217.

${ }^{7}$ Drummond $v$ Bisset (1551) Mor 12381; Cawdor v Cawdor 2007 SLT 152; Fisher v Applied Drilling Technology International Ltd [2016] $\mathrm{CSOH} 108$, at para 26.

${ }^{8}$ Macfarlane v Johnston (1864) 2 M 1210.

${ }^{9}$ Petrie $v$ Earl of Airlie (1834) 13 S 68.

${ }^{10}$ Whether or not there is such an intention is, as in the Anglo-American common law, assessed objectively: M Hogg 'Perspectives on contract theory from a mixed legal system' [2009] OJLS 643 at 662.

${ }^{11}$ Regiam Majestatem I, 28-31.

${ }^{12}$ Unlike in England and Wales, it cannot be said that patients do not contract with the Scottish NHS simply because consideration is not given by the patient. 'Gratuitous contracts make perfect sense in a system in which the validity of the unilateral promise is also recognised': Hogg, above n 10, at 652 .

${ }^{13} 2006$ SLT (Sh Ct) 141.

${ }^{14}$ Ibid, para 19.

${ }^{15}$ Over a decade prior to the decision, Professor Walker observed that 'medical cases [are] highly illustrative of the way in which particular conduct may be pleaded one way or another or in the alternative': see DM Walker 'The interaction of obligations and crime' in RF Hunter (ed) Justice and Crime: Essays in Honour of the Right Honourable the Lord Emslie (Edinburgh: T\&T Clark, 1993) p 16.

${ }^{16}[2015]$ UKSC 11.

${ }^{17}$ B Pillans Delict: Law and Policy (W Green, $5^{\text {th }}$ edn, 2014) para 6-05.

${ }^{18}$ [2013] CSIH 3, para 17; [2015] UKSC 11, para 74.

${ }^{19}$ Within Scots law, there existed a presumption that physicians would act in the best interests of their patients and, indeed, that their patients would in all cases hold a passive belief that the doctor would 'do what is best to care for the patient's health': see Moyes $v$ Lothian Health Board 1990 SLT 444, at 449 (per Lord Caplan).
} 
question. ${ }^{20}$ The only exception to this general position was where the information withheld concerned 'a substantial risk of grave adverse consequences, in which a judge could conclude, notwithstanding any practice to the contrary, that a patient's right to decide whether to consent to the treatment was so obvious that no prudent medical practitioner could fail to warn of the risk, save in an emergency or where there was some other cogent clinical reason for nondisclosure'. ${ }^{21}$

Although such may have been the letter of the law prior to 2015, the guidance given to doctors by the General Medical Council (GMC) at the time of that case, and indeed during Ms Montgomery's antenatal period and labour, differed in substance. The GMC enjoined physicians to 'respect patients' right to reach decisions with you about their treatment and care' in their document on 'Good Medical Practice' (2013), ${ }^{22}$ and the earlier (1998) edition of these guidelines was described as using words of 'broadly... similar effect' by the Court. ${ }^{23}$ Drawing on these guidelines, and other material such as the European Convention on Human Rights (ECHR) and English case law including Chester $v$ Afshar, ${ }^{24}$ the UKSC concluded in Montgomery that 'an adult person of sound mind is entitled to decide which, if any, of the available forms of treatment to undergo, and her consent must be obtained before treatment interfering with her bodily integrity is undertaken'. ${ }^{25}$

As there can be no doubt that this decision of the UKSC shifted the legal landscape of Scotland significantly, ${ }^{26}$ it appears that the basis of liability for negligent medical treatment, in this jurisdiction, requires reanalysis. 'To have a contract only when the patient pays [monetary consideration] is not consistent with a legal system which has no doctrine of consideration in contract'. ${ }^{27}$ A consent form is not simply a waiver which protects physicians from incurring legal liability; it is now quite clear that the prevailing regime of medical practice requires 'doctor and patient [to] reach agreement on what should happen' prior to treatment and consensual agreement (Latinised as consensus in idem) lies at the core of Scots contract law. ${ }^{28}$ Thus, it follows that Scots lawyers must consider the possibility that NHS physicians do not simply owe a duty of care ex delicto towards their patients, but may be bound by some ex voluntate obligation also.

In considering this question, this paper looks at the wider Scottish law of obligations, as this 'primary category' of law relates to 'medical law' and medical practice, ${ }^{29}$ and considers some core doctrinal differences between the law of Scotland and that of the rest of the United Kingdom. Recognising that across these jurisdictions there are not only important definitional differences between basic concepts such as 'contracts', and notable conceptual differences between the Scots law of delict and the Anglo-American law of torts, the present piece examines Scots law and Civilian concepts - such as negotiorum gestio (the unauthorised management of another person's affairs) ${ }^{30}$ - which have no presence in the common law tradition and asks whether they might be fruitfully applied in analyses of

\footnotetext{
${ }^{20}$ As Lords Reed and Kerr noted in the UKSC decision, 'the Hippocratic Corpus advises physicians to reveal nothing to the patient of her present or future condition, "for many patients through this cause have taken a turn for the worse" ([citing] Decorum, XVI)': Montgomery v Lanarkshire Health Board [2015] UKSC 11, para 74.

${ }^{21}$ Montgomery v Lanarkshire Health Board [2015] UKSC 11, para 27; see also Montgomery v Lanarkshire Health Board [2010] CSOH 104, para 233; [2013] CSIH 3, para 17.

${ }^{22}$ Available at https://www.gmc-uk.org/ethical-guidance/ethical-guidance-for-doctors/consent.

${ }^{23}$ Montgomery [2015], above n 21, para 79: see also the guidance available at https://www.gmc-uk.org/-/media/documents/ good-medical-practice-1998-55610424.pdf?la=en.

${ }^{24}[2004]$ UKHL 41.

${ }^{25}$ Montgomery [2015], above $\mathrm{n} 21$, para 87; the physician, however, will be exempted from this duty in cases of 'necessity', or where 'he reasonably considers that its disclosure would be seriously detrimental to the patient's health': para 88 .

${ }^{26}$ Though perhaps only in the sense that the decision caused practice to catch up with principle: see E Reid 'Montgomery v Lanarkshire Health Board and the rights of the reasonable patient' (2015) Edinburgh Law Review 360.

${ }^{27}$ WW McBryde 'Contract law - a solution to delictual problems?' (2012) SLT (News) 45 at 46.

${ }^{28}$ See eg Avintair Ltd $v$ Ryder Airline Services Ltd. 1994 SC 270 at 273, though note the need, also, for there to be an objectively ascertainable intention, on the part of the parties, to create legal relations: Dawson International plc $v$ Coats Paton plc (No 2) 1993 SLT 80 and see also Karoulias (WS) v The Drambuie Liqueur Co Ltd [2005] CSOH 112, para 50 per Lord Clarke.

${ }^{29}$ Of which, see SME Medical Law (Reissue), para 1.

${ }^{30}$ Of which, see NR Whitty and D Van Zyl 'Unauthorised management of affairs (negotiorum gestio)' in R Zimmerman et al (eds) Mixed Legal Systems in Comparative Perspective (Oxford: Oxford University Press, 2004) pp 367-398.
} 
'medical law' problems. In noting that the primary effect of the decision in Montgomery was that medical practitioners are now expressly enjoined by law to respect the dignity, humanity and 'personhood' of their patients, the paper consequently concludes that it is not only possible for Scots lawyers to develop these concepts so as to create a discrete and distinct Scottish medical jurisprudence, but that respecting the spirit of the decision of the UKSC in Montgomery effectively necessitates this course of action.

\section{Medical liability and the law of obligations}

\section{(a) Summa divisio obligationum}

'Medical law' (alternatively styled as 'healthcare law', or variations thereupon) emerged as a 'distinct, autonomous subject of legal study' only within the last century, ${ }^{31}$ however, as a 'contextual category' of jurisprudence, ${ }^{32}$ 'the body of law on which it draws is by no means new. ${ }^{33}$ The boundaries of 'medical law' may be difficult to delineate (such, as Professor Birks notes, is in the nature of contextual categories of law), ${ }^{34}$ but since the field of study is principally concerned with 'the relationship between health care professionals (particularly doctors and to a lesser extent hospitals or other institutions) and patients', ${ }^{35}$ the discipline necessarily draws upon 'primary categories' of private law. Though, then, reference is occasionally made to 'UK medical law' by commentators, such references are almost invariably conceptually inaccurate and inadequate. ${ }^{36}$ Parity of practical outcome, in particular cases or instances, in no way implies parity of law or juridical reasoning: hence, though Montgomery has been described as a 'UK medical law case' ${ }^{37}$ (and was decided by the UKSC), the consequences of this decision may well differ depending on whether one stands north or south of the Tweed.

Scots private law, as Whitty notes, was neither influenced nor hampered in its development by the English forms of action. ${ }^{38}$ Similarly, marking yet another distinction from the law of England, ${ }^{39}$ Scotland does not have a discrete law of 'torts' or 'delicts', ${ }^{40}$ but rather a broad and unitary law of obligations of which the law of delict forms but a part. ${ }^{41}$ As such, inter alia, Scots private law does not recognise a nominate delict or 'torticle' of negligence per se, ${ }^{42}$ but rather has developed in such a manner so as to recognise the possibility of delictual liability arising where loss has been caused through the negligent conduct of another. ${ }^{43}$ Drawing this distinction is no matter of mere hair-splitting

\footnotetext{
${ }^{31}$ SME Medical Law (Reissue) para 1.

${ }^{32} \mathrm{P}$ Birks 'Definition and division: a meditation on Institutes 3.13' in P Birks (ed) The Classification of Obligations (Oxford: Clarendon Press, 1997) pp 33-34.

${ }^{33}$ SME Medical Law (Reissue) para 3.

${ }^{34}$ Birks 'Meditation', above n 32, pp 33-34.

${ }^{35}$ I Kennedy and A Grubb Medical Law (London: Butterworths, 3rd edn, 2000) p 3.

${ }^{36}$ J Brown and S Christie 'Pater knows best? Withdrawal of medical treatment from infants in Scotland' (2020) 40(4) Oxford Journal of Legal Studies 682 at 683-684.

${ }^{37}$ See eg SW Chan et al 'Montgomery and informed consent: where are we now?' (2017) BMJ 357.

${ }^{38}$ NR Whitty 'The development of medical liability in Scotland' in E Hondius (ed) The Development of Medical Liability (Cambridge: Cambridge University Press, 2010) p 57.

${ }^{39}$ Of which, see B Rudden 'Torticles' (1991-1992) 6/7 Tulane Civil Law Forum 105, passim.

${ }^{40}$ There is, of course, a law of 'delict' (singular) under the umbrella of the general law of obligations: see WDH Sellar and HL MacQueen 'Negligence' in K Reid and R Zimmermann A History of Private Law in Scotland vol II (Oxford: Oxford University Press, 2000) p 518.

${ }^{41}$ The Stair Memorial Encyclopaedia, for instance, does 'reflect the institutional scheme, as for example by devoting one whole volume to the law of obligations'; P Birks 'More logic and less experience: the difference between Scots law and English law' in DL Carey Miller and R Zimmermann (eds) The Civilian Tradition and Scots Law: Aberdeen Quincentenary Essays (Berlin: Dunker \& Humblot, 1997) p 174, fn 20. See also HL MacQueen 'General concepts of obligations and contract in Scots law: from Stair to now' in D Bain et al Northern Lights: Essays in Private Law in Memory of Professor David Carey Miller (Aberdeen University Press, 2018) p 281. Contrast this with the position in England, where - insofar as the law of torts is concerned - 'the key word is in the plural': Rudden, above n 39, at 109.

${ }^{42}$ A Fagan 'Negligence' in Zimmermann et al, above n 30, p 498.

${ }^{43}$ Ibid.
} 
pedantry. In deducing the law from principles, rather than founding it on actions, 'Scots law... has [as a mixed jurisdiction] ${ }^{44}$ conformed more closely to the Civilian norm, rather than to the Common law'. ${ }^{45}$ This, as Birks observed, marks 'the true difference [between Scots and English law, which] consist $[\mathrm{s}]$ in the [Scots] commitment to the institutional scheme or, in other words, to a more systematic approach'. 46

Though Scots law has historically been influenced by the institutional schema of Justinian, ${ }^{47}$ the quadripartite division of obligations known to the Romans (obligations arising ex contractu, quasi ex contractu, ex maleficio and quasi ex maleficio $)^{48}$ was rejected by Stair, ${ }^{49}$ and so by subsequent Scots jurisprudence. ${ }^{50}$ Obligations, in Scotland, may be imposed ex lege [by law] (and so be styled 'involuntary obligations ${ }^{51}$ or, in Stair's parlance, 'obediential obligations') ${ }^{52}$ or they may arise as a result of one's own private, voluntary undertaking (and so be styled 'voluntary' [ie ex voluntate] obligations ${ }^{53}$ - termed 'conventional obligations' by Stair). ${ }^{54}$ Within the law of obligations, liability arising ex delicto has historically been contrasted with liability arising ex contractu, ${ }^{55}$ with the latter being conceived as the 'prime example of a "conventional" obligation'. ${ }^{56}$ While this divide between contract and delict has been termed summa divisio obligationum [the principal division of obligations], ${ }^{57}$ Scots law also recognises unilateral promises as species of ex voluntate obligations, ${ }^{58}$ and considers, inter alia, liability arising from an unjustified enrichment, or claims arising on the basis of negotiorum gestio, as species of involuntary obligations. ${ }^{59}$

The Anglo-American common law tradition knows of no equivalent to negotiorum gestio - indeed, lawyers schooled within that tradition would likely regard a gestor as an 'officious intermeddler' if not 'an outright tortfeasor'. ${ }^{60}$ Scots law, though, corresponds here with the tradition of Continental European nations such as France ${ }^{61}$ and Germany ${ }^{62}$ in its impulse to 'praise and reward' one who takes steps to protect the interests of another, even where the intervenor lacks authorisation from

\footnotetext{
${ }^{44}$ Of which, see the discussion in the Hon Lord Gill 'Quo Vadis Leges Romanorum?' (2019) SLG 53.

${ }^{45}$ See Sellar and MacQueen, above n 40, p 518.

${ }^{46}$ Birks, above n 41, p 174.

${ }^{47}$ The Scottish 'Institutional writers' (of which, generally, see K Luig 'Institutes of national law' (1972) Juridical Review
} 193) usually wrote treatises termed 'Institutes' or 'Institutions', which 'were typically structured around the Roman law concepts of Persons, Things and Actions, although not uncritically so': HL MacQueen 'The law of obligations in Scots law' in R Schulze and F Zoll (eds) The Law of Obligations in Europe: A New Wave of Codifications (Munich: Sellier, 2013) p 214.

${ }^{48} \mathrm{~J} .3 .13 \mathrm{pr}-2$.

${ }^{49}$ Institutes I, 3, 2.

${ }^{50}$ See the discussion in WW McBryde 'Review of The Laws of Scotland: Stair Memorial Encyclopaedia Vol. 15' (1997) Edinburgh Law Review 400.

${ }^{51}$ DN MacCormick Legal Right and Social Democracy: Essays in Legal and Political Philosophy (Clarendon Press, 1982) p 190.

${ }^{52}$ Institutes I, 3, 2.

${ }^{53}$ MacCormick, above n 51, p 190.

${ }^{54}$ Institutes I, 3, 2.

${ }^{55}$ As elsewhere in those jurisdictions influenced by the Continental European legal tradition: R Zimmermann The Law of Obligations: Roman Foundations of the Civilian Tradition (Oxford: Oxford University Press, 1990) pp 10-11.

${ }^{56}$ Sellar and MacQueen, above n 40, p 518.

${ }^{57}$ In Gaius' Institutes, obligations - other than those arising in the law as it relates to succession - are divided into two species: contract and delict: Gai Institutiones, III, 88. This, as du Plessis notes, strongly implies that the text in D.44.7.1pr (Gaius) is interpolated and that the Justinianic fourfold division of obligations is a post-classical expansion on an original binary divide between contract and delict: PJ du Plessis Borkowski's Textbook on Roman Law (Oxford: Oxford University Press, $6^{\text {th }}$ edn, 2020) p 255.

${ }^{58}$ TB Smith 'Pollicitatio - promise and offer' in Studies Critical and Comparative (W Green, 1962) p 168.

${ }^{59}$ These subjects are treated as ex lege obligations within the Stair Memorial Encyclopaedia - see Volume 15, Title 3.

${ }^{60}$ JP Dawson 'Negotiorum gestio: the altruistic intermeddler' (1961) Harvard Law Review 817 at 817.

${ }^{61}$ Of which, see Code Civil, Book II, Title IV ('of Undertaking Formed without an Agreement), translated by Georges Rouhette, Professor of Law, with the assistance of Dr Anne Rouhette-Berton, Assistant Professor of English.

${ }^{62}$ Of which, see Bürgerliches Gesetzbuch (BGB), Book II, Division 8, Title 13 'Geschäftsführung ohne Auftrag'. 
that person. Negotiorum gestio was 'borrowed by [Scots] law from the Roman law' ${ }^{36}$ and 'adopted practically without change ${ }^{64}$ - hence, the law of Scotland recognises that the actions of a gestor may create a relationship which gives rise to reciprocal rights and duties on the part of the gestor and the person whom they have intervened to aid. ${ }^{65}$ As with obligations arising from an unjustified enrichment, with which negotiorum gestio was historically identified, ${ }^{66}$ the obligations which arise from this relationship are imposed ex lege. ${ }^{67}$ They are not (strictly speaking) voluntarily undertaken by the gestor, nor by the party who benefits from the actions of the gestor.

Within the context of the Civilian tradition, the divide between 'voluntary' and 'involuntary' obligations was drawn neatly by Zimmermann (who, of course, recognised that 'the borderline between contract and delict is by no means as clear as might be imagined'). ${ }^{68}$ The former is said to pertain to the body of rules concerned with the fulfilment of expectation, while the latter concerns those rules which serve to safeguard the status quo (requiring reparation, repetition or restitution in the event of an upset thereof). ${ }^{69}$ Promises, like contracts, are self-evidently prospective in outlook, while all actions for unjustified enrichment are definitionally concerned with repetition of the status quo ante. Negotiorum gestio might be thought of as quasi-contractual, ${ }^{70}$ but Scots law does not resort to the fiction of an 'implied contract' to explain the operation of this concept. Instances of negotiorum gestio are said to give rise to a claim which 'has a solid foundation in justice, and in human nature, without necessity of recurring to the strained supposition of a contract'. ${ }^{71}$ The Latin phrase quasi-ex contractu, thus, cannot be translated literally, or with reference to contracts, within Scotland. ${ }^{72}$ As a species of involuntary obligation, the actions arising from negotiorum gestio are properly concerned with the preservation of the status quo and, through the obligation to compensate the gestor, with effecting a return to the status quo ante (insofar as money can achieve this recompense). ${ }^{73}$

\section{(b) Expectations, negotiorum gestio and medical treatment}

The provision of medical treatment, in the most general terms, may be viewed as either concerned with achieving the direct fulfilment of a person's positive expectations (ie in visiting my physician, I expect that their treatment should benefit me) or with preserving the status quo (ie I hope that the attending physicians, through their efforts, will be able to keep my presently incapax mother alive). In all cases, at the very least, all patients and their families are entitled to expect that the status quo itself (that is, the patient's current status of health) will not be upset further through the wrongdoing of any healthcare professional $^{74}$ - but this is no different from the position arising from any other human interaction. ${ }^{75}$ Any person - physician or otherwise - who is at fault for causing another's loss or

\footnotetext{
${ }^{63}$ Per Lord Anderson in A S Kolbin \& Sons $v$ William Kinnear \& Co 1930 SC 724 at 757.

${ }^{64} \mathrm{AC}$ Black and H M'Kechnie 'Agency' in Lord Dunedin and J Wark (eds) Green's Encyclopaedia of the Laws of Scotland (Edinburgh: W Green, 1926) para 587.

${ }^{65}$ SME Volume 15, Obligations, para 123.

${ }^{66}$ Stair Institutions I, 8, 3.

${ }^{67}$ SME Volume 15, Obligations, Title 3 (2).

${ }^{68}$ Zimmermann, above n 55, p 11.

${ }^{69}$ Ibid.

${ }^{70}$ Stair Institutions I, 8, 3.

${ }^{71} \mathrm{H}$ Home, Lord Kames Principles of Equity $(1825,5$ th edn) p 118, note (a).

${ }^{72}$ SME Volume 15, Obligations, para 91.

${ }^{73}$ Bankton Institutes I, 9, 24.

${ }^{74}$ That is, it is expected that the conduct of the physician will not be wrongful and will not worsen the patient's condition. 'In the most extensive possible sense, [an obligation of reparation] may arise both in the context of a breach of promise and entirely independently of a promissory obligation': MacCormick, above n 51, p 212.

${ }^{75}$ As Professor Walker observed, 'medical negligence is not different in principle from any other kind of professional negligence... the concept is of failure to take the care which is reasonable in the circumstances. The application of the concept may be different because of the circumstances, but the concept itself is not different and does not have different meanings': Walker, above n 15, pp 16-17. To this, it might be added that the same is true not only in respect of negligence, but in instances of intentional or injurious (ie contumelious) wrongdoing also.
} 
'personal injury' is liable to repair that loss or personal injury due to the operation of the law of delict. $^{76}$

The appropriate analysis will depend on the particular nature of the treatment which is sought. A prospective - and thus contractual or promissory - analysis of the situation has clear benefits in cases of cosmetic surgery, as in all such cases the status quo is thought undesirable. Doctor and patient agree that a physiological change should be made and the patient expects that this change will occur while they submit to surgery. Conversely, in instances in which an incapax patient is treated there can be unless otherwise expressed ahead of time, for example, through an advance directive ${ }^{77}$ - no fulfilment of expectation on the part of the patient as there can be no expectation of any kind on the part of the patient at the time of treatment. The operating physician is, here, in the position of a benevolent intervenor seeking restoration of the status quo ante, or the maintenance of the status quo.

This latter scenario describes, on the face of it, a quintessential instance of negotiorum gestio: the physician has usefully, but without authorisation from the incapax, acted for the good of the incapax patient. ${ }^{78}$ While 'almost any act in the conduct of another's affairs may amount to negotiorum gestio, ${ }^{79}$ and there has been academic commentary which suggests that analysing the physician/incapacitated patient relationship as being one of negotiorum gestio would be fruitful, ${ }^{80}$ the law of Scotland has not yet expressly taken this step. ${ }^{81}$ Such is unfortunate from the perspective of any jurisprudent, since negotiorum gestio could be used to explain the existence and operation of controversial concepts such as the 'medical exception' within this jurisdiction. ${ }^{82}$ It is also unfortunate from the standpoint of anyone who is opposed to the lingering presence of undue paternalism in medical law and ethics. Drawing on the earlier work of Professor TB Smith, Meyers has suggested that the law pertaining to negotiorum gestio could be developed so as to justify a move away from the traditional (paternalistic) 'best interests' standard in medical decision-making, ${ }^{83}$ insofar as the care of incapax adults (and certain children $)^{84}$ are concerned. ${ }^{85}$ In employing negotiorum gestio in preference to the "best interests test', 'the fundamental enquiry will become "do we know or can we find out what the patient would want done under the circumstances at hand?" Not, "What do we think is 'best' for the patient?"'86

The former question would appear to be more in keeping with the spirit of the judgment in Montgomery than the latter. The decision in that case enjoins physicians to recognise the humanity of those whom they treat: as noted in the judgment of Lords Reed and Kerr, patients are and ought to be seen as 'persons holding rights', not merely regarded 'as the passive recipients of the care of the medical profession' ${ }^{87}$ Having regard to an individual's personhood or 'personality' necessarily entails having a respect for that person's personality interests, whether the person is capax or

\footnotetext{
${ }^{76}$ As Watson notes, it is... a characteristic of legal rules that they are habitually general in the sense that they apply to various different situations and various kinds of people... the result is that unless legal rules are divided to fit the various classes of users, the rules will fail to adequately respond to needs'. In Justinianic Roman law, 'so far as the proposition that lack of skill equals negligence is concerned, no distinction is drawn between a doctor and a mule driver': see A Watson Failures of the Legal Imagination (University of Pennsylvania Press, 1988) p 72 at p 76. See also D.9.2.8.1 (Gaius) and D.9.2.27.34 (Ulpian).

${ }^{77}$ See eg the discussion in S Christie 'Advance decisions, dementia and subsequent inconsistent behaviour: a call for greater clarity in the law' (2019) 7(1) Journal of Medical Law and Ethics 1.

${ }^{78}$ See SME Volume 15, Obligations, para 95.

${ }^{79}$ Ibid, para 96.

${ }^{80}$ TB Smith A Short Commentary on the Law of Scotland (Edinburgh: W Green, 1962) p 632; TB Smith 'Law, professional ethics and the human body' (1959) SLT 245 at 246.

${ }^{81}$ SME Volume 15, Obligations, para 102

${ }^{82}$ Though see J Brown 'When the exception is the rule: rationalising the medical exception in Scots law' (2020) 26(1) Fundamina: A Journal of Legal History 1.

${ }^{83}$ DW Meyers 'TB Smith: a pioneer of modern medical jurisprudence' in EC Reid and DL Carey Miller A Mixed Legal System in Transition: T.B. Smith and the Progress of Scots Law (Edinburgh: Edinburgh University Press, 2005) p 209.

${ }^{84}$ See s 2(4) of the Age of Legal Capacity (Scotland) Act 1991.

${ }^{85}$ Meyers, above n 83, pp 207-208.

${ }^{86}$ Meyers, above n 83, p 209.

${ }^{87}$ Montgomery [2015], above n 21, para 75.
} 
incapax at the relevant time. 'Autonomy', of course, 'seems to be a personality [as opposed to proprietary] right ${ }^{88}$ and is recognised as a core interest relevant to medical decision-making in common, Civilian and Mixed jurisdictions alike. ${ }^{89}$ Negotiorum gestio, in this context, provides a ready-made framework onto which a medico-legal regime which prioritises respect for personality interests, such as 'autonomy', might be superimposed. The law can - and indeed, in systems which recognise negotiorum gestio, does - presume that the average citizen would willingly accept benevolent intervention were they in a position to do so (ie were they not absent or incapax), but where there is evidence to suggest that the citizen in question would actively reject the gestor's intervention (however objectively beneficial) the law regards the unwarranted intervention as a wrong. ${ }^{90}$

This corresponds with the 'patient-empowering' (or patient-participating) policy objectives of modern medical (and medico-legal) practice. ${ }^{91}$ The net effect of the decision in Montgomery is to place 'the wants, needs and reasonably held expectations of patients... at the apex of judicial reasoning. ${ }^{92}$ Negotiorum gestio excuses reasonable interference with the interests of the incapax where there is a reasonable presumption that the incapax would have given the gestor a mandate for their interference. ${ }^{93}$ Where there is evidence to suggest that the incapax would not have assented to any such interference, however, the intervenor is not properly speaking a gestor but is rather a delinquent - that is, the false gestor has committed a delictual wrong (whether through a negligent, reckless or malicious design is here irrelevant, as the significance of the classification of the conduct will depend on the nature of the interest interfered with). Extending the analysis of negotiorum gestio to the doctor/ patient relationship would mean that a medical practitioner who acts in what they reasonably believe to be the interests of an incapax patient will be a gestor and so be deemed to be acting lawfully and within the confines of a relationship of negotiorum gestio. ${ }^{94}$ One who hubristically acts against, or without regard to the known or presumed wishes of the patient, will, however, commit the delict of assault. $^{95}$

Adopting the negotiorum gestio analysis outlined above would not materially change the requirements for a successful suit against a negligent physician. A gestor who fails to achieve a successful result through fault in their intervention may be liable, in delict, to the absent or incapax person whom they have sought to aid. ${ }^{96}$ The question of the liability of a gestor was, in Roman law, controversial, ${ }^{97}$ although a gestor was certainly liable for actions which displayed dolus (maliciousness) or culpa lata (the utmost degree of fault)..$^{98}$ In Scots law, a gestor has long been recognised as obliged

\footnotetext{
${ }^{88}$ Holdich $v$ Lothian Health Board [2013] CSOH 197, para 102, per Lord Stewart.

${ }^{89}$ See Brown and Christie, above n 36, at 691.

${ }^{90}$ Alongside the rules of negotiorum gestio, it remains the case that generally speaking 'culpa est immiscere se rei ad se non pertinenti' ['to involve oneself in a thing that does not pertain to oneself is a fault']: D.50.17.36 (Pomponius). See also Bankton Institute I, 9, 24.

${ }^{91} \mathrm{R}$ Heywood and J Miola 'The changing face of pre-operative medical disclosure: placing the patient at the heart of the matter' (2017) LQR 296.

${ }^{92}$ Ibid, at 300 .

${ }^{93}$ SME Volume 15, Obligations, para 87.

${ }^{94}$ This would, as Smith notes, provide a justification in surgery cases in which, while operating on an incapax patient, the physician notices and, with a benevolent motive, thereafter removes a diseased organ: Smith (1962), above n 80, p 632; Smith (1959), above $n$ 80, at 246-247.

${ }^{95}$ Though Scots law uses the terminology of 'assault', the concept of an 'assault' in the Scots law of delict is quite distinct from that which subsists in common law jurisprudence. The taxonomy of 'trespass to the person' was never received into Scots law; the roots of the Scots concept lie in the Roman actio iniuriarum: see Brown, above n 82, at 6.

${ }^{96} \mathrm{SME}$ Volume 15, Obligations, para 121.

${ }^{97}$ Zimmermann, above n 55, p 445.

${ }^{98}$ D.3.5.3.9 (Ulpian). Of course, 'the distinction between intent recklessness and maliciousness was never truly drawn by the Romans' (see K McK Norrie 'The actio iniuriarum in Scots law: romantic Romanism or tool for today?' in E Descheemaeker and H Scott (eds) Iniuria and the Common Law (Oxford: Hart Publishing, 2013) p 54, but it has long been recognised that 'culpa lata quae equiparatur dolo' ['the utmost degree of fault is the equivalent of maliciousness']: Callendar v Milligan (1849) 11 D 1174, at 1176 per Lord MacKenzie. See also Zimmermann, above n 55, p 447.
} 
to 'bestow a degree of care and diligence [which] alter[s] with circumstance'. 99 Traditionally, as in the law of delict, there were said to be three degrees of fault for which one might be liable: culpa lata, culpa levis (ordinary, or slight fault) and culpa levissima (the slightest degree of fault). ${ }^{100}$ The standard of care expected of a gestor varied depending on the circumstances of the case, with a gestor acting in circumstances of necessity liable only for demonstrating dolus or culpa lata, ${ }^{101}$ with one acting as gestor in ordinary circumstances held liable for ordinary negligence or fault (culpa levis). ${ }^{102}$ A false gestor - that is, a genuinely officious intermeddler who involved themselves in another's affairs without cause, or contrary to that person's expressed wishes ${ }^{103}$ - was held liable for the officious intermeddling alone, ${ }^{104}$ rationalised in this context as liability for culpa levissima. ${ }^{105}$

By the latter half of the nineteenth century, the tripartite distinction between degrees of fault in delict became a bipartite distinction. The Inner House rejected the distinction between culpa levis and levissima in MacKintosh $v$ MacKintosh ${ }^{106}$ and held that a party who engages in a risky venture 'should exercise the care and diligence which a prudent man would observe in his own affairs, and which a prudent and conscientious man will observe as to the interests of his neighbours' ${ }^{107}$ By the turn of the twentieth century, the bipartite distinction was abandoned, ${ }^{108}$ having fallen out of fashion. ${ }^{109}$ Thus, in Hunter $v$ Hanley, ${ }^{110}$ Lord Russell found that in civil claims based on negligence, and including claims against professional men, there is... only one standard, viz., the absence of reasonable care in the circumstances or ordinary culpa. ${ }^{111}$

Just as the distinction between degrees of fault was abrogated in the law of delict, so too was it abandoned in the context of negotiorum gestio. Foreshadowing his celebrated decision in the (Scottish) case of Donoghue $v$ Stevenson ${ }^{112}$ by a year or so, in 1931 Lord Atkin opined that while 'what measure of care is required from a negotiorum gestor in respect of goods over which he assumes control has been the subject of much discussion... the more scientific treatment of the problem is not to predicate different degrees of negligence [ie culpa, or "fault" in this context], ${ }^{113}$ but to concentrate on the duty, breach of which constitutes negligence. The duty is to take reasonable care in the circumstances, and will vary in each case, but, having been discharged, negatives any negligence, lata, levis, or levissima. ${ }^{114}$ In effect, then, the existence of a negotiorum gestio relationship negates, in cases of purportedly negligent conduct, any question as to whether or not a duty of care is or ought to be owed; the question becomes simply whether or not the gestor exercised the requisite standard of care expected in the circumstances.

Extending the concept of negotiorum gestio to cover matters of medical practice would not, as the above analysis indicates, change terribly much in respect of ordinary cases of negligent malpractice. A physician who fails to exercise the expected level of care in treating their patient will be adjudged by

\footnotetext{
${ }^{99} \mathrm{P}$ Shaw A Treatise on the Law of Obligations and Contracts (T\&T Clarke, 1847) p 234.

${ }^{100} \mathrm{DM}$ Walker The Law of Delict in Scotland (W Green, $2^{\text {nd }}$ edn, 1981) p 200; Erskine Institute III, 1, 21; III, $3,53$.

${ }^{101}$ Erskine Institute III, 3, 53.

${ }^{102}$ Ibid.

${ }^{103}$ The existence of a contract between the parties will exclude any possibility of a claim based upon benevolent intervention': see MacQueen and Thomson, above n 1, para 1.42.

${ }^{104}$ Shaw, above n 99, p 234.

${ }^{105}$ This could also be readily conceived as contumelia rather than, or in addition to, culpa.

${ }^{106}(1864) 2$ M 1357.

${ }^{107}$ Ibid, at 1362 per Lord Neaves.

${ }^{108}$ See Farquhar v Murray (1901) 3 F 859; Whitty, above n 38, p 59.

${ }^{109}$ 'The question in each case is whether, in its circumstances, fault in the ordinary sense of that word is proved': SS 'Baron Vernon' v SS 'Metagama' 1927 SC 498 per Lord Justice-Clerk Alness at 509.

${ }^{110} 1955$ SC 200.

${ }^{111} \mathrm{Ibid}$, at 207.

${ }^{112} \mathrm{SC}(\mathrm{HL}) 31$.

${ }^{113}$ There has long existed a (false) impression that "what a lawyer meant by culpa in Scotland was the same as "negligence" in England'. Though this impression is not correct in its particulars, it has been assumed by a great many (reputable) judges and jurists: see Smith (1962), above n 80, pp 658-659.

${ }^{114}$ Kolbin \& Sons $v$ Kinnear \& Co SS 'Altai' 1931 SC (HL) 128, at 139.
} 
the same delictual standard whether the relationship between doctor and incapax patient is conceived of as one of negotiorum gestio or not. A physician who subjects an incapax patient to an untested or novel form of treatment without having first obtained the knowledge or consent of that patient would still be liable in a claim for delictual assault. ${ }^{115}$ Adopting the negotiorum gestio analysis outlined above would, however, allow for a more ready and rational departure from the standard of 'best interests' in medical decision-making, in a manner consistent with the decision in the case of Montgomery. It would also bring a level of coherence to Scottish medical jurisprudence which is presently lacking. This, it is submitted, would be a boon to practitioners and jurisprudents alike; there is, after all, 'nothing so practical as a good theory.' ${ }^{116}$

\section{(c) 'Injury' ('personal' and otherwise), assythment and medical treatment}

The influence of Roman law on the Scottish reception of negotiorum gestio is obvious, but Scotland's connection to the Continental European Civilian tradition was of the utmost importance in the development of the wider Scots law of obligations also. ${ }^{117}$ Historically, the maxim spondet peritam artis et imperitia culpae adnumeratur [one promises skill in one's art and the lack of such skill is a fault $]^{118}$ was of importance in the Scots law of ex lege and ex voluntate obligations alike, ${ }^{119}$ since the law of reparation of damnum (damage) in delict is predicated on the occurrence of the delinquent's culpa [fault] ${ }^{120}$ and the brocard was (to adopt anachronistic English parlance) implied into all contracts of the hire of services. ${ }^{121}$ However, within Roman law itself, the art of medicine was treated amongst the artes liberales and so - unless the physician was a slave or libertini let out to perform their art under a contract of lease or hire ${ }^{122}$ - physicians were not, socially, regarded as artisans selling or contracting out their labour. ${ }^{123}$ Work arising as from obligation to another, rather than altruism, was seen in Rome as a sordid activity, ${ }^{124}$ fit only for slaves. ${ }^{125}$ For the Romans, then, the basis of liability for medical malpractice generally arose within the context of the law of delicts, rather than of contracts. ${ }^{126}$

Delictual actions for damage done to the body (ie 'personal injury') through culpable, but unintentional, wrongdoing were initially barred in Roman-Scots law, ${ }^{127}$ as throughout the law in the Continental Europe ius commune, ${ }^{128}$ since the actio de damno dato (action for damage done) which became common currency throughout the courts of ius commune legal systems, was said to

\footnotetext{
${ }^{115}$ Brown, above n 82, at 28-29.

${ }^{116}$ See AJM Steven et al (eds) Nothing so Practical as a Good Theory: Festschrift for George L Gretton, (Avizandum, 2017).

${ }^{117}$ See the discussion in A Watson Legal Transplants: An Approach to Comparative Law (University of Georgia Press, $2^{\text {nd }}$ edn, 1993) p 36.

${ }^{118}$ Dig 50.17.132 (Gaius); Dig 19.2.9.5 (Ulpian, citing Celsus).

${ }^{119}$ See the pursuer's argument in Farquhar v Murray (1901) 38 SLR 642.

${ }^{120}$ Of which, see G MacCormack 'Culpa in the Scots law of reparation' (1974) Jur Rev 13.

${ }^{121}$ The application of the maxim is not confined to regulated professions, but applies to any and all persons who undertake, or profess to undertake, the provision of services in a skilled art: see ICL Tech Ltd v Johnston Oils Ltd 2012 SLT 667, para 23 (per Lord Hodge); French $v$ Strathclyde Fire Board 2013 SLT 247, para 43 (per Lord Drummond-Young) and Red Star Pub Company Ltd $v$ Scottish Power Ltd [2016] CSOH 100, para 248 (per Lord Boyd of Duncansby).

${ }^{122}$ Zimmermann, above n 55, p 387.

${ }^{123}$ See Watson, above n 76, pp 77-78; N Žiha 'Medicus between perception and reality as portrayed in some non-legal sources' in VM Minale and V Amorosi History of Law and Other Humanities (Dykinson, 2019) p 276.

${ }^{124}$ Zimmermann, above n 55, p 387.

${ }^{125}$ See Watson, above $\mathrm{n} 76, \mathrm{p} 78$.

${ }^{126}$ Ibid, p 78.

${ }^{127}$ Though actions of assythment - a native Scots action and remedy - were permitted, and remained permitted for a time, where the conduct which led to 'death or personal injury' was criminal - see the discussion below.

${ }^{128} \mathrm{DW}$ McKenzie and R Evans-Jones 'The development of remedies for personal injury and death' in R Evans-Jones (ed) The Civil Law Tradition in Scots Law (The Stair Society, 1995) p 277.
} 
be based on the lex Aquilia. ${ }^{129}$ The Roman lex Aquilia was a statute allowing for the recovery of property damage caused by wrongful conduct (damnum injuria datum) ${ }^{130}$ Since it was held, in Roman law as in the later ius commune, that dominus membrorum suorum nemo videtur [no one is to be regarded as the owner of their own limbs], ${ }^{131}$ it followed that a freeman (or woman sui iuris) ${ }^{132}$ could not sue in their own name for 'personal injury.' ${ }^{133}$ One could not claim 'damages' for harm effected to one's body, since one's body was not an object in one's patrimony (ie one's own body is not, in life, one's 'property' in law). ${ }^{134}$ To obtain redress for wounds inflicted upon the body, one would have to succeed in an actio iniuriarum, which was functionally confined to occasions of calculated wrongdoing. ${ }^{135}$ 'Hence there was no fertile soil here for the growth of medical malpractice; an action for deliberate assault would seldom be appropriate'. ${ }^{136}$

Since the body of a free person is (at least so long as it is 'inhabited' by some 'spirit or soul' ${ }^{137}$ - in other words, for as long as the free person is alive) not a 'thing', in law, ${ }^{138}$ it was held that it could not be 'damaged' in any monetary sense. ${ }^{139}$ 'The Romans seem to have treated seriously their maxim that the body of a free person is beyond price'; ${ }^{140}$ under the influence of this Roman rule and Christian theology alike, mediaeval and early modern lawyers did likewise. ${ }^{141}$ Thus, 'while [following negligent injury to their body, a free person] could claim damages for medical expenses and loss of earnings, ${ }^{142}$ [they] could not claim for other non-patrimonial types of harm because of the principle that a freeman's body is of inestimable value'. ${ }^{143}$ As in Rome, wrongs to the body were reparable only where there was 'injury' in the sense of iniuria (ie in the sense of the nominate delict, as opposed to its sense in the context of damnum iniuria datum), ${ }^{144}$ and not merely where the victim suffered 'personal injury' in the modern sense of that term. ${ }^{145}$

Iniuria was an etymologically complex Latin term, but in the context of the actio iniuriarum it specifically denoted contumelious (hubristic) ${ }^{146}$ conduct which affronted the existimatio (a collective term for all 'personality interests') of a persona. ${ }^{147}$ Used in this sense, iniuria could be inflicted by words (and so be termed iniuria verbalis or 'verbal injury') or by deeds (and so be termed iniuria realis

\footnotetext{
${ }^{129}$ That said, the modern Aquilian action, in the words of the eighteenth-century German jurist Thomasius, 'differs more from the [true Roman] Aquilian action than a bird from a four-footed beast': C Thomasius Larva Legis Aquiliae Detracta Actioni de Damno Data Receptae in Foro Germanorum (Halle, 1703) s 1.

${ }^{130}$ McKenzie and Evans-Jones, above n 128, p 277.

${ }^{131}$ D.9.2.13pr (Ulpian).

${ }^{132}$ In Roman law, absent any indication to the contrary 'the term 'hominis' undoubtedly includes men and women', per D.50.16.152 (Gaius) and 'the use of a word in the masculine gender is usually extended to cover both genders' D.50.16.195 (Ulpian). See also D.3.5.3.1 (Ulpian).

${ }^{133}$ McKenzie and Evans-Jones, above n 128, p 280.

${ }^{134}$ JVM Welie et al Ownership of the Human Body: Philosophical Considerations on the Use of the Human Body and its Parts in Healthcare (London: Kluwer, 1998) p 69.

${ }^{135}$ Watson, above n 76, p 71.

${ }^{136}$ Ibid, p 71.

${ }^{137}$ Smith (1959), above n 80, at 245.

${ }^{138}$ Welie et al, above n 134, p 69.

${ }^{139}$ See Dig 9.3.7 (Gaius).

${ }^{140}$ Watson, above n 76, p 73.

${ }^{141} \mathrm{~J}$ Blackie 'Unity in diversity: the history of personality rights in Scots law' in NR Whitty and R Zimmermann Rights of Personality in Scots Law: A Comparative Perspective (Dundee University Press, 2009) p 85.

${ }^{142}$ See eg Scot (1675) Argyll Justiciary 68; Dewar v Baxter (1662) Justiciary Records 53; McNiccoll (1680) Argyll Justiciary 128.

${ }^{143}$ Blackie, above n 141, p 85.

${ }^{144}$ Of which see J Brown 'Dignity, body parts, and the actio iniuriarum: a novel solution to a common (law) problem?' (2019) Cambridge Quarterly of Healthcare Ethics 522 at 522.

${ }^{145}$ See J Brown 'Law reform, legal transplants and developing the law of defamation' (2020) SLG (forthcoming).

${ }^{146}$ Of which, see D Ibbetson 'Iniuria: Roman and English' in Descheemaeker and Scott, above n 98, p 40.

${ }^{147}$ J Brown 'O tempora! O mores! The place of boni mores in dignity discourse' (2020) Cambridge Quarterly of Healthcare Ethics 144 at 145.
} 
or 'real injury'). ${ }^{148}$ Affronts caused by iniuria did not give rise to any claim for 'damages', ${ }^{149}$ since properly speaking 'damages' serve only to repair instances of patrimonial loss (damnum). ${ }^{150}$ Rather, reflecting the fact that the actio iniuriarum served as a means to repair non-patrimonial hurt, the remedies for 'injury' were either non-pecuniary or punitive. ${ }^{151}$ The key punitive pecuniary remedy for affront, solatium, ${ }^{152}$ came however to be 'effortlessly reinterpreted as being purely compensatory when the time came for legal writers to fit the actio iniuriarum into the modern theory of Scots delict law'. ${ }^{153}$

That solatium and 'damages' are conceptually separate has been consistently overlooked in Scottish legal theory and practice. ${ }^{154}$ Indeed, ironically, while bemoaning the neglect and maltreatment of the actio iniuriarum within Scottish jurisprudence, Professor TB Smith himself described solatium as a form of 'damages for non-patrimonial loss'. ${ }^{155}$ This misunderstands the simple fact that an award of damages exists to repair damnum (loss) while a compensatory award of solatium is granted in recognition that iniuria has been inflicted, even if that iniuria occurs ultimately sine damno (ie even if the contumelious conduct does not cause the victim 'loss'). This is not to say that a pursuer can raise and win an actio iniuriarum without demonstrating that they suffered harm at the hands of the defender; ${ }^{156}$ it is merely the case that the threshold for 'harm' is lower in cases where solatium is sought in an actio iniuriarum than in cases where damages are sought for damnum iniuria datum. ${ }^{157}$ Mere upset or annoyance does not constitute 'loss', but it most certainly can evidence an 'affront' in circumstances in which the defender has ostensibly committed iniuria. ${ }^{158}$

The neat divide between the Roman actions, and the associated remedies, for patrimonial loss and non-patrimonial affront was, from the outset of the Scottish reception of Roman law, blurred due to the extant customary Scots law relating to harms effected to the body. ${ }^{159}$ Prior to the reception of, and thereafter alongside the received, Roman law, Scotland recognised its own native penal action and compensatory remedy of assythment. ${ }^{160}$ By the nineteenth century, the word 'assythment' had - in addition to its dual meaning denoting both action and remedy - a further dual meaning, denoting

\footnotetext{
${ }^{148}$ For a full discussion of the taxonomy of iniuria in early modern Scots law see Blackie, above $\mathrm{n}$ 141, passim.

${ }^{149}$ The Scots monetary remedy for an actio iniuriarum - solatium - has been described as a form of 'damages' (see WJ Stewart Reparation (Edinburgh: W Green, 2000) para 18-1), but conceptually 'damages' and 'solatium' are distinct from one another: solatium may be ordered sine damno (without loss). It may be awarded as a means of 'acknowledging' the pursuer's 'wounded feelings'; see Smith v Comrie's Executors 1944 SC 499 at 500.

${ }^{150}$ See Stevens $v$ Yorkhill NHS Trust 2006 SLT 889, para 63: in principle solatium for "hurt feelings" caused by affront based upon the actio injuriarium is a different animal to the solatium that can be awarded to a claimant for physical or psychiatric injury. Prima facie the threshold for recovery for hurt feelings is lower than that for psychiatric injury'. In other words, reparation may be made under an actio iniuriarum without the pursuer having presented proof of 'loss'.

${ }^{151}$ Unlike in English law, where the divide between tort and crime emerged at a relatively early stage (see M Dyson and J Randall 'England's splendid isolation' in M Dyson (ed) Comparing Tort and Crime (Cambridge: Cambridge University Press, 2015) p 19), the rules of Scots delict and crime developed largely in parallel until the nineteenth century: J Blackie 'The interaction of crime and delict in Scotland' in M Dyson (ed) Unravelling Tort and Crime (Cambridge: Cambridge University Press, 2014) p 358.

${ }^{152} \mathrm{~A}$ term which was not, in fact, used in the Roman sources themselves: E Descheemaeker 'Solatium and injury to feelings: Roman law, English law and modern tort scholarship' in Descheemaeker and Scott, above n 98, p 68.

${ }^{153}$ Ibid, p 73 .

${ }^{154}$ See the discussion in J Brown 'The Defamation and Malicious Publication (Scotland) Bill 2019: an undignified approach to law reform?' (2020) SLT (News) 131 at 131-132.

${ }^{155}$ TB Smith 'Designation of delictual actions: damn, injuria, damn' (1972) SLT (News) 125 at 126.

${ }^{156}$ For the requirements of a successful actio iniuriarum, see Brown, above n 147, passim and the discussion in Brown, above n 82 .

${ }^{157}$ Stevens, above n 150, at 902.

${ }^{158}$ Cruickshanks v Forsyth (1747) Mor 4034.

${ }^{159}$ See J Blackie 'The protection of corpus in modern and early modern Scots law' in Descheemaeker and Scott, above $\mathrm{n} 98$, p 155.

${ }^{160}$ See R Black 'A historical survey of delictual liability in Scotland for personal injuries and death' (1975) 8(1) Comparative and International Law Journal of Southern Africa 46 at 53.
} 
both ('in its "proper" sense') ${ }^{161}$ 'the composition payable on the commission of a crime', but also ('in the more general sense') ${ }^{162}$ 'the right to reparation for personal injury [ie for bodily wounds or death inflicted on a person through the actions of another] generally, even where there was no criminal prosecution'. ${ }^{163}$ The monetary remedy of assythment served the dual purpose of repairing instances of 'loss', in the sense of damnum, but also of affording emotional redress to the wounded, or the family of the deceased. Per Balfour, assythment was payable to 'to the kin, bairnis, and freindis [of a deceased person], in contentatioun of their damage, and for pacifying of thair rancor'; ${ }^{164}$ as Professor Black notes 'however, only one lump sum was awarded, and there was no formal division of the amount into so much for patrimonial loss, and so much for moral damages [which might be here termed, anachronistically, solatium]'. ${ }^{165}$

Although assythment - as an action and remedy - was said to be available only where the conduct of the defender was 'criminal', it must be borne in mind that a great deal more conduct fit under this heading in early modern Scots law than would fit within the definition of 'criminal' conduct today. ${ }^{166}$ There was no meaningful separation of crime and delict in Scotland until the nineteenth century. ${ }^{167}$ Furthermore, while it would have been perfectly logical, and perhaps desirable, for eighteenth century Scots law to have required that a defender actually be convicted by the appropriate Scottish criminal court before finding assythment due... it was not the law. ${ }^{168}$ The action for and remedy of assythment was consequently available throughout the eighteenth century for all cases of 'mutilation and demembration $^{\text {,169 }}$ which were in the Continental European legal tradition species of iniuria realis, and for cases of negligent or culpable homicide as well as murder alike. ${ }^{170}$ Thus, in spite of the position within Roman jurisprudence, 'the proposition that damages [as well as what would now be called solatium] were available in cases of bodily injury in the Court of Justiciary was trite. It was observable in "daily practice"'. ${ }^{171}$

Notwithstanding the evident utility of the action for assythment, the action began a process of terminal decline from the early eighteenth century onwards. This decline can be linked to the corresponding rise of the modern Scots law of actionable negligence predicated on culpa, which is widely regarded to have its genesis in the (unreported) ${ }^{172}$ case of Gardner v Ferguson in $1795 .{ }^{173}$ Medical malpractice lawsuits - alleging infringement of the body, rather than a failure of skill in reporting medical information or diagnosis ${ }^{174}$ - seemingly did not occur in Scotland until the twentieth century, ${ }^{175}$ at which time the action for and remedy of assythment was neither well-understood nor commonly utilised by Scottish lawyers. Scots law had, by that time, been pulled in two distinct directions by its connections to the two great legal traditions - the Continental European Civilian

\footnotetext{
${ }^{161}$ See Greenhorn v Addie (1855) 17 D 860 at 864 per Lord President McNeill.

${ }^{162}$ Lady Leith Hall $v$ Earl of Fife (1768) Mor 13904.

${ }^{163}$ McKenzie and Evans-Jones, above n 128, p 296.

${ }^{164}$ PGB McNeill (ed) The Practicks of Sir James Balfour of Pittendreich: Vol 2 (Edinburgh: The Stair Society, 1963) p 519.

${ }^{165}$ See Black, above n 160 , at 62 .

${ }^{166}$ Mere negligence alone was not criminal by the later eighteenth century, however; hence in the seminal (though unreported) case of Gardner $v$ Ferguson (1795), 'the pursuer did not refer at all, even by way of mere analogy, to the action of assythment, but based his claim almost entirely on Roman Law, and in particular, upon Dig 92 Ad Legem Aquiliam. And this line of argument was accepted by the Court': R Black 'A historical survey of delictual liability in Scotland for personal injuries and death, (Part II)’ (1975) 8(2) Comparative and International Law Journal of Southern Africa 189 at 190.

${ }^{167}$ See above n 151.

${ }^{168}$ Black, above n 160 , at $69-70$

${ }^{169}$ See eg the style for 'Doom for demembering' provided by Sir George MacKenzie The Laws and Customes of Scotland, In Matters Criminal. Wherein is to be seen how the Civil Law, and the Laws and Customs of other Nations do agree with, and supply ours (Edinburgh: James Glenn, 1678) p 286.

${ }^{170}$ Malloch, Petitioner (1751) Mor 11774 at $11,779-11,780$.

${ }^{171}$ Blackie, above n 141, p 88.

${ }^{172}$ 'The first reported [original author's emphasis] case in which the new action was accepted' was, according to Professor Black, Innes v Magistrates of Edinburgh (1798) Mor 13189: see Black, above n 166, at 190.

${ }^{173}$ EJH Schräge Negligence: The Comparative History of the Law of Torts (Berlin: Duncker and Humboldt, 2001) p 8.

${ }^{174}$ See eg Urquhart $v$ Grigor (1864) 3 M 283.

${ }^{175}$ Blackie, above n 159, 'Corpus', p 161.
} 
tradition and that of the English common law - and neither of these sources of legal culture possessed a grammar by which assythment could be readily rationalised. English law wholly and explicitly rejected the concept of assythment, ${ }^{176}$ while the idea of a single action and remedy to afford reparation for patrimonial 'loss' and non-patrimonial 'injury' simultaneously was distinctly un-Roman. That there was confusion in the provenance of Scottish claims for death or 'personal injury' is consequently unsurprising. ${ }^{177}$

Ultimately, assythment - as a remedy and thus also as an action - was abolished by section 8 of the Damages (Scotland) Act 1976. ${ }^{178}$ This statutory intervention came after the House of Lords, in the 1972 case of McKendrick $v$ Sinclair,${ }^{179}$ held that Scottish common law actions and doctrines cannot fall into desuetude. ${ }^{180}$ Until the legislature intervened at this juncture, it remained (theoretically) possible for a litigant to succeed in a claim for this remedy. ${ }^{181}$ Still, it was consistently passed over by lawyers and litigants in favour of the general Civilian reparative action, based on the lex Aquilia, which was extended beyond its original confines as a proprietary remedy to afford reparation in cases of 'personal injury'. That solatium - along with damages - became available in such actions 'seems to have been grafted from the earlier redress of assythment and not from the actio iniuriarum of Roman law'. ${ }^{182}$

Although the 'proper' actio iniuriarum was received into Scots law, ${ }^{183}$ the action has been sorely neglected in Scots jurisprudence for over two centuries. ${ }^{184}$ Still, the potential for a revival remains present ${ }^{185}$ and - indeed - development of the action would be of practical as well as analytical benefit to lawyers and litigants in Scotland. ${ }^{186}$ This is particularly so in light of the decision in Montgomery; a physician who, contrary to the decision in that case, subjects a patient to a form of treatment to which the patient has not expressly consented unquestionably interferes with that patient's autonomy. As indicated in the 2013 case of Holdich $v$ Lothian Health Board, it can plausibly be argued that 'autonomy' is not an interest which might be damnified, ${ }^{187}$ although in that case a claim for 'loss of autonomy' was recognised as 'not per se irrelevant [and] as capable of forming part of a claim for solatium as it is of supporting a standalone claim'. ${ }^{188}$ Logically, since "autonomy" in this context seems to be a personality [as opposed to proprietary] right', ${ }^{189}$ and since solatium is said to be the appropriate remedy for interference with this non-patrimonial 'personality right', the basis of the right of action would be the actio iniuriarum, which serves in Scotland - as it did in Rome - to repair instances of affront to personality, rather than loss of [part of] one's patrimony.

To succeed in such an action, a pursuer need only demonstrate that the defender behaved contumeliously towards them in infringing a recognised 'personality interest'. ${ }^{190}$ Subjective affront to a

\footnotetext{
${ }^{176}$ Blake v Midland Rly Co (1852) 21 LJ QB 233.

${ }^{177}$ For a commentary on the confusion, stemming from the judgment of the court in Eisten $v$ North British Railway Co (1870) 8 M 980, see Smith, above n 155, passim and TB Smith 'Damn, injuria, again' (1984) SLT (News) 85.

${ }^{178}$ This legislation has, however, since been repealed in its entirety by s 16 of the Damages (Scotland) Act 2011.

${ }^{179} 1972$ SLT 110.

${ }^{180}$ In the words of Lord Reid 'loss of a common law remedy by desuetude would I think be a novelty in our law and I see no advantage in introducing such a principle. No one knows what may happen in the future': ibid at 113.

${ }^{181}$ Black, above n 160 , at 65 .

${ }^{182}$ Smith (1962), above n 80, p 649.

${ }^{183}$ HL MacQueen 'Case comment: actio iniuriarum and human organ retention' (2007) Edinburgh Law Review 5; see also MacKenzie, above n 169, p 303; Bankton Institute I, 10, 21-39.

${ }^{184}$ EC Reid Personality, Confidentiality and Privacy in Scots Law (W Green, 2010) para 17-12.

${ }^{185}$ In South Africa - where the actio iniuriarum has thriven, particularly since the introduction of the 1996 Constitution the action likewise suffered a long period of neglect before being revived so as to allow reparations in claims for affront to 'personality interests': see J Burchell 'Personality rights in South Africa: re-affirming dignity' in Whitty and Zimmermann, above n 141, p 639.

${ }^{186}$ Brown, above n 144 , passim.

${ }^{187}$ Holdich $v$ Lothian Health Board, above n 88, para 3.

${ }^{188}$ Ibid, para 102.

${ }^{189}$ Ibid.

${ }^{190}$ Brown, above n 82
} 
recognised interest is not sufficient, however; it is for the court, on examination of the facts, to make a determination of whether or not the conduct complained of is (properly speaking) 'injurious'. ${ }^{191}$ This determination is made according to the 'admittedly nebulous' standard of boni mores, ${ }^{192}$ which in contemporary parlance is comparable to the familiar standard of 'public policy'. ${ }^{193}$ In other words, conduct is 'injurious' if it causes sufficient subjective 'affront' to move a person to initiate a court action and if it is also thought by the court to have objectively overstepped the bounds of acceptable conduct, which is measured according to the prevailing norms of society. ${ }^{194}$

Since the decision in Montgomery, what is thought - in the medico-legal sphere - to constitute 'acceptable conduct' according to modern mores has been modified considerably. While at one time a considerable degree of latitude was afforded to physicians in carrying out their practice, ${ }^{195}$ in a legal order in which patients are properly regarded as 'persons holding rights [and] exercising choices', ${ }^{196}$ medical practitioners are constrained in the exercise of their profession. To achieve the standard of care expected of a competent physician, said physician must take 'reasonable care to ensure that the patient [is] aware of any material risks involved in any recommended treatment, and any reasonable alternative or variant treatments' ${ }^{197}$ This alone, however, is insufficient to properly afford protection to the recognised 'personality interests' of patients. Were a physician to proceed with an operation without properly obtaining consent from their patient, or without informing them of alternative treatment options, it would, however, be difficult to frame an Aquilian action for damages (ie an action predicated on the physician's culpa) in the event that the physician's chosen treatment proved successful. The physician's actions would, in this case, be iniuria (wrongful), but iniuria sine damno (wrongful conduct without 'loss') does not give rise to any right of reparation in an action of this kind.

Thus, again, to comply with the spirit, as well as the letter, of the decision in Montgomery there must, in law, be some means of protecting the personality interests of patients which does not concern itself with questions of quantification or 'loss'. As with negotiorum gestio in respect of incapax patients, the development of the actio iniuriarum would afford Scots lawyers with a ready-made framework - already present within the Scottish legal system - from which a robust means of protecting 'personality interests' might be developed. Development of this Scottish legal resource would allow patients who are subjected to medical treatment without their consent, or subjected to (even successful) medical treatment without first having been made aware of the full suite of treatment options available to them, an action to obtain solatium for the infringement of their personal autonomy. This right of action would be grounded in judicial recognition of the fact that, in the twenty-first century, any physician who high-handedly elects to proceed with their preferred form of treatment without 'respect[ing their] patients' right to reach decisions with [them] about their treatment and care' acts hubristically.

\footnotetext{
${ }^{191}$ See eg Le Roux and Others $v$ Dey 2010 (4) SA 210 (SCA).

${ }^{192}$ SA Strauss 'Bodily injury and the defence of consent' (1964) South African Law Journal 179 at 183; Zimmermann, above n 55, p 1058.

${ }^{193}$ Brown, above n 147, at 145.

${ }^{194}$ Brown, above $\mathrm{n} 82$, at 17.

${ }^{195}$ Consider eg Urquhart $v$ Grigor (1864) 3 M 283, in which 'when the pursuer learnt what sort of [medical] examination was intended she remonstrated against it as immodest. But, disregarding her objections, the defender insisted upon examining, and did examine, her person'. Although such conduct would certainly constitute iniuria according to twenty-first century norms (consider Professor Reid's comment on Henderson v Chief Constable, Fife Police 1988 SLT 361, in Reid, above n 184, para 2.20), the contentious issue in this case was not whether the physician had hubristically subjected a woman to an invasive examination against her will, but rather whether or not he had been negligent or malicious in preparing a factually false report following from that examination; the examination itself, and the circumstances in which it was conducted, were not seen as immoral or unlawful.

${ }^{196}$ Montgomery [2015], above n 21, para 75.

${ }^{197}$ SME Medical Law (Reissue), para 181 (update).
} 


\section{(d) Consent, contracts and medical treatment}

While it is plain that 'the full potential of negotiorum gestio [or, indeed, actio iniuriarum] ${ }^{198}$ in Scots law has not, or has not yet, been realised, ${ }^{199}$ and although Roman law dealt with matters of medical malpractice almost wholly through the lens of its law of delicts, Scots law has historically recognised that a contract exists where doctor and patient reach consensus in respect of the treatment which is to be afforded. ${ }^{200}$ Indeed, it was not until the 1914 case of Edgar $v$ Lamont ${ }^{201}$ that it was found (in peculiar circumstances) that medical practitioners owe, in delict, a duty of care to their patients. ${ }^{202}$ This delictual duty, logically in line with the principles of Scots law, is owed in addition to any extant contractual obligations. ${ }^{203}$ The case of Edgar, however, was not merely decided at a time in which patients were not properly recognised as 'persons holding rights', but indeed at a time in which women (particularly married women) ${ }^{204}$ were not fully or properly recognised as 'persons' at all. ${ }^{205}$

In Edgar, the pursuer's husband contracted with a physician (Dr Lamont) to secure medical treatment for her. This was par for the course in the early twentieth century; 'medical attendance was one of the necessaries of family life, for which the husband as head of the family was liable'. ${ }^{206}$ Though Dr Lamont had contracted with Mrs Edgar's husband to treat her injured finger, Lamont was (it appears grossly) negligent in his provision of treatment, with the net effect that Mrs Edgar's maltreated finger caused her 'great pain' and ultimately had to be amputated. ${ }^{207}$ Although Scots law at this time recognised at common law the concept of a jus quaesitum tertio (third party 'right' arising from contract), ${ }^{208}$ for reasons which are not clear from the case report, ${ }^{209}$ Mrs Edgar - rather than her husband - elected to sue Dr Lamont and predicated her claim on the law of delict rather than the law of contract. ${ }^{210}$

Compounding the issue, the defender sought to argue that in a lawsuit predicated upon a contract 'the only person with a title to sue is the person with whom the contract was made'. ${ }^{211}$ This proposition was quite consistent with the relevant English law of the day, ${ }^{212}$ but was not at all in keeping with the then-prevailing position in Scots law. ${ }^{213}$ Nevertheless, founding on English legal principles and authorities, the Court of Session ultimately held that 'a patient is entitled to a direct action ex delicto against a doctor for professional incompetence or negligence' since 'to hold otherwise would lead to an entire denial of any remedy to a person who did not happen to be the person who had contracted with

\footnotetext{
${ }^{198}$ See the discussion above.

${ }^{199}$ Whitty and Van Zyl, above n 30, p 368.

${ }^{200}$ Whitty, above n 38, p 58; Edgar v Lamont (1914) 51 SLR 208.

${ }^{201} 1914$ SC 277.

${ }^{202}$ Whitty, above n 38, pp 58-59.

${ }^{203}$ The Court of Session, in that case, found that 'no action lies in respect of the injuries so sustained at the instance of the person (other than the patient) who contracted for the doctor's services' ( $p$ 279), but this must be mistaken in law; as discussed below, the Court predicated its findings upon pleadings which relied upon English, rather than Scots, law here. For the position in Scots law proper see M Hogg 'Concurrent liability in the Scots law of contract and delict' (1998) Jur Rev 1; Realstone Ltd $v$ Shepard and Others [2008] CSOH 31, paras 10-11; McBryde, above n 27, at 46.

${ }^{204}$ Consider eg the Income Tax Act 1918, which defined (in s 237) one who is incapax for the purposes of the legislation as 'any infant, married woman, lunatic, idiot, or insane person'.

${ }^{205}$ Recall the observations of Professor Esposito that 'the more human beings that an individual manages to place on the sloping plane of the thing, the more solidly he or she acquires the title of person': R Esposito Persons and Things (Polity Press, 2015) p 27.

${ }^{206}$ Edgar, above n 200, at 280 .

${ }^{207}$ Ibid, at 277 .

${ }^{208}$ See the discussion in J Brown 'Jus quaesitum tertio: a res, not a right?' (2019) Juridical Review 53.

${ }^{209}$ Mrs Edgar's action was brought 'with the consent and concurrence of her husband': Edgar, above n 200 , at 277.

${ }^{210}$ Interestingly, just as the facts of Edgar follow the model of a jus quaesitum tertio, though this was never pled, so too did the facts of Donoghue v Stevenson 1932 SC (HL) 31: see McBryde, above n 27, at 45.

${ }^{211}$ Edgar, above n 200, at 279.

${ }^{212}$ As was made expressly clear, the following year, in Dunlop Pneumatic Tyre Co $v$ Selfridge \& Co Ltd [1915] AC 847.

${ }^{213}$ See Love $v$ Amalgamated Society of Lithographic Printers of Great Britain and Ireland 1912 SC 1078; Scots law has recognised the enforceability of jus quaesitum tertio since the sixteenth century: Wood v Moncur (1591) Mor 7719.
} 
the doctor'. ${ }^{214}$ The veracity of this finding might well be doubted, particularly since 'Scots law historically recognised that an individual may sue the parties to a contract, notwithstanding the fact that said individual was never party to that contract, if the individual in question explicitly or implicitly benefits from the grant of a jus quaesitum tertio, ${ }^{215}$ but this notwithstanding, Scottish legal practitioners came to recognise delictual actions as the primary means of securing reparation in cases of medical malpractice. $^{216}$

With the advent of the National Health Service (NHS) ${ }^{217}$ and National Health Service (Scotland) (NHS (S) $)^{218}$ following in the wake of World War II, the idea that a physician might directly contract with their patient had already largely died away. Indeed, when the case of Hunter $v$ Hanley ${ }^{219}$ called before the Court of Session in 1955 the notion that the case might proceed upon the grounds of a contract was not at all explored, nor was the significance (or otherwise) of the then-recent National Health Service (Scotland) Act 1947 on the liability of a physician, or the Secretary of State, touched upon either. The pursuer predicated her claim in Hunter upon the defender's alleged culpa (fault) ${ }^{220}$ and did not succeed in her claim as it was found by the court that the defender, Dr Hanley, had in his actions achieved the requisite standard of care expected in the circumstances. Since this time, 'with the assimilation of the law on the standard of care', it has been said that 'there is very little difference between English law and Scots law on medical negligence'. ${ }^{21}$

There remain, however, notable and significant differences between the English law of contracts and the Scots law of ex voluntate obligations. In England and Wales, services under the NHS are (typically, as yet) provided 'free at the point of use' and so no contract is concluded between serviceprovider and service-user. ${ }^{222}$ While there might exist agreement between service-provider and service-user, or while the service-provider may undertake to make some promise to the service-user, bare promises are not enforceable in English law and to be enforceable as a contract an agreement must typically be underpinned by consideration, ${ }^{223}$ which is necessarily lacking in cases involving NHS practitioners and their patients. ${ }^{224}$ In Scotland, by contrast, since the concept of a 'gratuitous' contract - and indeed gratuitous unilateral obligations - has long been recognised, the lack of exchange or underpinning 'consideration' between NHS physician and patient is no bar to the recognition of a contract between them.

As noted in the introduction to the present paper, this was recognised in the 2006 case of Dow $v$ Tayside University Hospitals NHS Trust, although ultimately it was found that no contract or enforceable promise was formed within the facts of that case. Indeed, Sheriff Fletcher considered that a contract (or unilateral promise) would be constituted in respect of an NHS physician/patient relationship only if 'it was clear that the doctor concerned was exceptionally entering into a contract and was not relying on the statutory relationship [predicated the National Health Service (Scotland) Act 1978] alone'. ${ }^{25}$ The circumstances in which this would occur, Sheriff Fletcher admitted, were unlikely and difficult to conceive of; ${ }^{226}$ they would also be such as to place an 'additional burden', or additional duties, on the healthcare provider. ${ }^{227}$ Nonetheless, Dow is notable for correctly recognising that unlike

\footnotetext{
${ }^{214}$ Edgar, above n 200, at 279.

${ }^{215}$ Brown, above n 208, at 55.

${ }^{216}$ Whitty, above n 38, pp 58-60.

${ }^{217}$ National Health Service Act 1946 (c 81).

${ }^{218}$ National Health Service (Scotland) Act 1947 (c 27).

${ }^{219} 1955$ SC 200.

${ }^{220}$ Ibid, at 201.

${ }^{221}$ Whitty, above n 38, p 63.

${ }^{222}$ T Krebs 'Unintended side-effects of the National Health Service' in I Goold et al (eds) Persons, Parts and Property: How Should We Regulate Human Tissue in the $21^{\text {st }}$ Century? (Oxford: Hart Publishing, 2014) p 39.

${ }^{223}$ Chitty, above n 2, para 4-001.

${ }^{224}$ Krebs, above n 222, p 39.

${ }^{225}$ Dow, above n 13 , at para 19.

${ }^{226}$ Ibid.

${ }^{227}$ Ibid.
} 
in England and Wales, there is no bar, in theory, to the recognition of an ex voluntate obligatory relationship between NHS (S) service-providers and service-users.

In spite of this, it remains the case that 'the current orthodoxy is that, as a generality, no contractual relationship exists' in such circumstances. ${ }^{228}$ This orthodoxy is, however, predicated upon three propositions which are demonstrably false or irrelevant to a claim within the context of Scots law: 'the first being the absence of a statutory power to contract; the second being that statutory agencies, such as health boards, which are legally obliged to do something are not free to contract to do that thing; and the third principle being that patients and other service users do not (in general) provide consideration for services received'. ${ }^{29}$ The last of these three propositions clearly runs counter to the basic principles of Scots law, as has been demonstrated throughout this paper, but such did not prevent discussion of the point in the Outer House of the Court of Session, in the case of Holdich v Lothian Health Board. ${ }^{230}$ Nonetheless, the position advanced by the pursuer in Holdich was unquestionably sound viz Scots law: 'the absence of any need for contractual consideration in Scots law enlarges the opportunities for statutory providers to contract'. ${ }^{231}$

This is certainly the case, just as it is also the case that, as Lord Stewart recognised, there was no principled reason that a statutory health board could not enter into contracts in the absence of express statutory authority. ${ }^{232}$ As the pursuer argued in Holdich, 'health authorities do make contracts daily' and, in answer to the second alleged 'principle' barring recognition of a contractual relationship between NHS (S) physician and patient, though a health authority is statutorily obliged to provide 'treatment', '[a] consent form completed by the pursuer [might] demonstrate that the pursuer had freedom to make stipulations' with the net effect that 'the normal rules of contract apply unless there is conflict with statutory functions'. ${ }^{233}$ Although Lord Stewart ultimately concluded that 'the pursuer's property-contract case... as it has been presented at this stage, faces difficulties', ${ }^{234}$ his Lordship expressly recognised that 'consenting to medical treatment need not be inconsistent with contracting for medical treatment'. ${ }^{235}$ The difficulties faced by the pursuer were largely concerned with the framing of their argument: 'as the defenders correctly point out the there is a shortage of detail in the pleadings, at this stage, to support the idea of contractual intention'. ${ }^{236}$

That Scots law can recognise the relationship between NHS (S) physicians and their patients as predicated on an ex voluntate obligation is thus apparent. That Scots law should recognise this is likewise clear. As Professor McBryde noted in a 2011 address before Compass Chambers, ${ }^{237}$ there are sound public policy reasons for recognising the existence of contracts between NHS (S) physicians and their patients. 'If those who pay for medical treatment have more rights than the majority who do not, the law is discriminatory, defective and unfair. ${ }^{238}$ McBryde's observation has been placed into sharper focus since the decision in Montgomery, in which it was recognised that patients are seen as 'consumers exercising choice'. ${ }^{239}$ If patients are increasingly afforded the opportunity to choose alternative (private-sector) healthcare providers in preference to NHS (S) services, then it is imperative that the basis of liability for private medical malpractice be rationalised on the same basis as liability for medical malpractice which follows from 'free at the point of use' provision. This is particularly so when, as

\footnotetext{
${ }^{228}$ See Holdich $v$ Lothian Health Board, above n 88, para 60 per Lord Stewart.

${ }^{229}$ Ibid, para 65.

${ }^{230} \mathrm{Ibid}$, paras 60-65. For recent comment on the proprietary and delictual aspects of this case see KGC Reid 'Body parts and property' in Bain et al, above n 41, pp 235-260 and EC Reid 'Delictual liability in Holdich v Lothian Health Board' in the same volume at p $261 \mathrm{ff}$.

${ }^{231}$ Holdich $v$ Lothian Health Board, above n 88, para 61.

${ }^{232}$ Ibid, para 65.

${ }^{233}$ Ibid, para 61 .

${ }^{234}$ Ibid, para 75 .

${ }^{235}$ Ibid, para 76 .

${ }^{236}$ Ibid, para 76 .

${ }^{237}$ Revised and published as McBryde, above n 27.

${ }^{238} \mathrm{Ibid}$, at 46.

${ }^{239}$ Montgomery [2015], above n 21, para 75.
} 
in Scotland, there is no legal formal bar to the recognition of gratuitous contracts between doctor and patient.

Affording a patient who has 'jumped the queue' additional rights, even if those additional rights amount only in practice to the right to plead alternate claims in their action, ${ }^{240}$ would place NHS (S) patients at a disadvantage relative to those who receive private healthcare. While 'no doubt it is sometimes difficult to distinguish between liability arising from breach of contract and liability arising from breach of duty ${ }^{241}$ and, indeed, in Scots law, breach of certain types of contract may give rise to a claim for solatium as well as of damages, ${ }^{242}$ it remains the case that there are occasions in which proof of a contract might benefit a pursuer who would otherwise require to predicate their claim on the law of delict alone. It appears, for instance, that if a contract of deposit is breached, and sentimentally important property is lost or damaged as a result of that breach, then the pursuer might claim monetary compensation ascertained with reference to the pretium affectionis ['price of affection'] associated with the thing. ${ }^{243}$ There is, it might be thought, less scope for such recovery within the law of delict.

The practical issues faced in the pleadings submitted by Ms Dow and Mr Holdich in their respective cases are - or can be - likewise mitigated following from the decision in Montgomery. While Dow and Holdich each stumbled due to a lack of specification in the terms of the purported ex voluntate obligation, the fact that medical practitioners are now expressly expected to reach agreement, with their patient(s), as to the form of treatment which that patient is to undergo means that there necessarily will be evidence of the terms of the discussion between doctor and patient. If such evidence is absent, then it is a prima facie indication that the physician has committed a delictual wrong, since it is injurious to proceed with treatment in the absence of the patient's consent. Where such evidence is present however, legal practitioners ought to be able to readily interpret the terms of that discussion as obligatory or not, ${ }^{244}$ depending on the particular facts of the particular case. There is, after all, no formal requirement that contractual terms (other than those concerned with real rights in land) ${ }^{245}$ be in writing in order to be given legal effect. ${ }^{246}$ Intention to create legal relations must be inferred from the fact that, objectively speaking, any physician who agrees to respect a patient's choice must surely understand that they will be bound in law to do so.

The above discussion is not to say that a contractual analysis of the NHS (S) physician/patient relationship will be appropriate in all cases. Rather, this paper has simply sought to argue that it is, in Scots law, possible to recognise this relationship as contractual and that in some - indeed, perhaps many - cases, this would be of benefit to lawyers, physicians and patients alike. All of these groups would benefit from a more rationalised Scottish medical jurisprudence which is consistent with the wider norms of Scots private law. ${ }^{247}$ Altogether more practically, however, recalling Zimmermann's

\footnotetext{
${ }^{240}$ MacQueen and Thomson, above n 1, para 1.39 .

${ }^{241}$ Edgar, above n 200, at 279 per Lord Salvesen.

${ }^{242}$ See VV Palmer 'Contracts of intellectual gratification - a Louisiana-Scotland discovery' in VV Palmer and EC Reid Mixed Jurisdictions Compared: Private Law in Louisiana and Scotland (Edinburgh: Edinburgh University Press, 2009) pp 208-243.

${ }^{243}$ Lockhart $v$ Cunninghame (1870) SLR 8151.

${ }^{244}$ It should be noted here that, though Scots law recognises that an enforceable unilateral obligation may be created by a bare promise alone, since the introduction of s 1(2)(1)(ii) of the Requirements of Writing (Scotland) Act 1995 (c 7), writing is a formal requirement for the creation of any 'gratuitous unilateral obligation except an obligation undertaken in the course of business'. While it may be thought that an NHS (S) physician who makes a unilateral undertaking to their patient is not acting 'in the course of business', due to the absence of profit motive, this question is complicated in the case of physicians in private practice. This could, it is submitted, lead to the undesirable situation - discussed above - wherein a private patient potentially has, in practice, more options or entitlements than does an NHS (S) patient. As this (potential) issue arises from the construction of a statute, it would take legislative intervention to rectify the problem (if this situation be deemed such).

${ }^{245}$ Ibid, s $1(2)(a)(i)$.

${ }^{246}$ Ibid, s 1(1).

${ }^{247}$ Admittedly this benefit is fundamentally abstract and conceptualised as a 'benefit' perhaps only in the skewed and biased view of one peculiarly-minded jurisprudent.
} 
observations that the law of ex voluntate obligations is primarily concerned with the fulfilment of expectation, ${ }^{248}$ it is quite clear that it is more appropriate to invoke the law of contract than the law of delict in cases of frustrated expectation. Since 2015, NHS (S) patients have been imbued with a legitimate expectation that any decisions with respect to their medical treatment will be made in partnership with their physician(s) and only then after the patient has expressly consented. Thus, it would be in keeping with common sense, as well as with the fundamental principles of Scottish jurisprudence, to regard any relationship in which consensus in idem through mutual agreement has been achieved as contractual, rather than regarding the breach of an agreement as a delictual matter.

\section{Conclusion}

Prior to (and largely post - for much of the commentary on the case has been Anglo-centric in focus) the decision in Montgomery, 'the Scottish case law on medical non-disclosure [was] somewhat sparse, relatively elderly and at times badly reported, with the effect that the Scots law on this subject has not, or not yet, experienced a "medical litigation revolution". ${ }^{249}$ One might go further than this in noting that Scottish medical jurisprudence, in general, has largely been held back in its development by the poor reporting - and limited discussion - of those native authorities and sources of authority which exist. Due to these lacunae, Scottish legal practitioners have generally forsaken arguments predicated on the principles of Scots law and instead have given, in medico-legal matters, undue weight to English doctrines and authorities. This has occurred even in cases where the principles of Scots law notably differ, or in which native Scots (or received Civilian) concepts might have been more fruitfully employed.

Such can directly be seen from the case of Edgar v Lamont, wherein an argument predicated on the operation of the Scottish doctrine of jus quaesitum tertio could have benefited the pursuer, but instead protracted litigation - ultimately decided in a manner consistent with the rules of a foreign legal system - followed from her counsel's (conscious or otherwise) decision to forgo arguing this point. The noted phenomenon is also the root cause of the present 'orthodoxy' that no contract is formed between NHS (S) physician and their patient. This supposed orthodoxy is quite out of keeping with the principles of the Scots law of ex voluntate obligations; the idea that, to be enforceable as a contract, an agreement must be underpinned by consideration is not at all Scottish. As such, following from the decision in Montgomery $v$ Lanarkshire Health Board, which holds that patients are entitled to expect to reach decisions as to their medical treatment in 'partnership' with their physician(s), ${ }^{250}$ it appears that there is an impetus for Scottish medico-legal practitioners to consider the possibility that a contract is formed when agreement as to how to proceed is achieved between physician and patient. While it will not be the case that a contract is formed in all such instances, the possibility should at least be borne in mind when crafting pleadings.

It should also be borne in mind, when considering the present framework of Scottish medical jurisprudence, that Scots law recognises a number of doctrines and concepts which have no ready comparators in the Anglo-American legal world. The actio iniuriarum was received into Scots law and the concept of iniuria ('injury') which operates therein, rather than any notion of 'trespass', continues to govern the Scots delict of 'assault' (inter alia). Thus, legal practitioners and commentators should be aware of the fact that a failure to obtain or respect consent from a patient could be, in Scotland, conceptualised as a hubristic affront to the 'personality interests' of the patient which might give rise to a claim for solatium. From the recognition, in Montgomery, that patients are to be conceived of as 'persons', it clearly follows that the law must develop an effective means of protecting non-patrimonial 'personality rights'. Whatever position may abide in the common law, Scots law possesses a(n

\footnotetext{
${ }^{248}$ Zimmermann, above n 55, p 11.

${ }^{249}$ SME Medical Law (Reissue), para 259.

${ }^{250}$ Montgomery [2015], above n 21, para 78.
} 
admittedly under-developed) framework to allow for reparation in cases in which the 'personality interests' of a patient are harmed, even if no 'loss' ultimately results from the wrongdoing.

Another doctrine which has no ready comparator in - indeed, which is ostensibly anathema to Anglo-American jurisprudence, but which is present in Scots law and could be effectively developed to be of use in medico-legal matters, is that of negotiorum gestio. The idea that one who benevolently acts for the good of an incapacitated person commits no wrong is clearly in keeping with the norms of present medical practice. More than this, however, as demonstrated above adopting a negotiorum gestio analysis of medical treatment would also allow the Scottish courts to give effect to the spirit, as well as the letter, of the decision of the UKSC in Montgomery. The doctrine provides a means by which the standard of 'best interests' might be abandoned - either in whole or in part - as the focus of the enquiry in any purported case of negotiorum gestio is, as Meyers recognised, "do we know or can we find out what the patient would want done under the circumstances at hand?" Not, "What do we think is 'best' for the patient?"'251 By bearing in mind that there exists no unitary 'UK legal system', and that Scots jurisprudence is an altogether different animal from common law, Anglo-American lawyers can ensure that they do not overlook a potentially fruitful avenue for wider comparative scholarship.

The above analyses would involve the Scottish courts, as well as Scottish practitioners and legal commentators, breaking from the present tradition of relying on Anglo-American materials in medico-legal matters. That is, however, no bad thing; traditionally, as Professor Birks noted, Scots law has adhered more to the systematic norms of Civilian jurisprudence than to slavish adherence to precedent. ${ }^{252}$ Speaking on the topic of Scots law generally, in 1935 Lord Dunedin noted that '[though] different actions have different names, the question in Scotland was never as to the remedy it was always as to the right. You ask for what you want in your summons...You may not get what you want, but that will be because you failed to show that you had the right to get it'. ${ }^{253}$ In order for such a system to subsist, though, the law must be understood and rationalised. This necessitates the presence of a logical taxonomy which allows those who plead in court to contextualise their claim of right to a remedy in the correct manner, so that they can readily show that they (or their client) have the right to get the remedy which is claimed. This paper, it is hoped, provides - at least - the beginnings of such a taxonomy.

In any case, it is worth considering the words of Mr Justice van der Westhuizen of the South African Constitutional Court: 'Areas of law are labelled or named for purposes of systematic understanding and not necessarily on the basis of fundamental reasons for a separation. Therefore, rigid compartmentalisation should be avoided'. ${ }^{254}$ The onus is therefore on medical lawyers and jurisprudents - particularly in a legal order which has come to encourage the practice and study of particular specialisms over the possession of a broad knowledge base - to recall, in their practice or study, the principles of the fundamental 'primary categories' of law which underpin their specialty's subject-matter. 'Medical law', 'Health law' or whatever appellation is given to the topic is and remains a 'contextual category'. As such, in researching and crafting arguments concerning its doctrines, due attention must be paid to the interrelation of those areas of law which inform it. It is hoped that this paper will, at the very least, start a conversation about the practical and theoretical benefits, to Scottish legal practice and jurisprudence, of bearing these key points and principles in mind.

\footnotetext{
${ }^{251}$ Meyers, above n 83, p 209.

${ }^{252}$ Birks, above n 41, p 171.

${ }^{253}$ Lord Dunedin The Divergences and Convergencies of English and Scottish Law (Fifth lecture on the David Murray Foundation in the University of Glasgow, 21 May 1935).

${ }^{254}$ Gcaba $v$ Minister for Safety and Security 2010 (1) SA 238 (CC), para 52 per van der Westhuizen J.
}

Cite this article: Brown J (2021). Obligations, consent and contracts in Scots law: re-analysing the basis of medical malpractice liability in light of Montgomery $v$ Lanarkshire Health Board. Legal Studies 41, 156-176. https://doi.org/10.1017/ lst. 2020.40 